\title{
CAMPYLOBACTER SP IN EGGS FROM CLOACAL SWAB POSITIVE BREEDER HENS
}

\author{
Belchiolina Beatriz Fonseca $^{1 *}$; Ricardo Alfredo Soncini² ${ }^{2}$ Adelia Rodrigues Gimarães ${ }^{3}$; Daise Aparecida Rossi ${ }^{1}$ \\ ${ }^{1}$ Faculdade de Medicina Veterinária, Universidade Federal de Uberlândia, Uberlândia, MG, Brasil; ${ }^{2}$ Universidade do Oeste de \\ Santa Catarina, Campus Xanxerê, SC, Brasil; ${ }^{3}$ Universidade de Minas Gerais, Uberlândia, MG, Brasil \\ Submitted: December 07, 2005; Returned to authors for corrections: May 15, 2006; Approved: July 18, 2006
}

\begin{abstract}
Campylobacter sp is a microaerophilic, thermotolerating Gram negative bacterium, known to be one of the main causes of food-borne human infections. Among the foods that carry these microorganisms, the chicken is outstanding. In Brazil, a large chicken exporting country, few researches are conducted about their prevalence in breeder hens and the transmission through eggs. The aim of this research was to verify the presence of Campylobacter sp in the shells and within the eggs from positive cloacal swab breeder hens. Microbiological analyses were made on cloacal swabs of 140 weighed breeder hens. The positive breeder hens were set aside and in a total of 244 of their eggs, Campylobacter sp was present in macerated shells and yolk contents during 7 weeks. Out of the 140 researched breeder hens, 25 (17.8\%) were positive from cloacal swabs, however the eggs were not positive. The physiological characteristics of the birds, their eggs and Campylobacter sp favor the bacterium entering and surviving in the eggs, but in this study, no positive result was found in macerated shells or in the yolks, indicating that vertical transmission is probably an unusual event.
\end{abstract}

Key words: Campylobacter, eggs, chicken, vertical transmission, epidemiology

\section{INTRODUCTION}

Thermotolerant Campylobacter sp has been outstanding as an emergent microorganism related to contamination of foods, mainly of bird origin, in several parts of the world (1). The intestinal content of poultry has been shown to be the main container of Campylobacter jejuni (8). Bird infection is generally not associated with clinical disease, even if large numbers of bacteria are expelled with the feces (5).

Many researches have been conducted to determine bird infection pathways. The main sources of grange site contamination seem to be contaminated feed, horizontal transmission, animals kept in an infected environment, and vectors such as, rodents, insects, wild birds, pets and humans (3).

Although horizontal transmission is well known, the role of vertical transmission continues to be discussed as an epidemiologically important way of fowl infection. In Brazil, an important chicken exporting country, there are few researches to investigate Campylobacter sp epidemiology. This knowledge may contribute to the search for alternatives to control chicken contamination.

The purposes of this study was to verify the presence of the Campylobacter sp in eggs from cloacal swabs positive breeder hens and determine the potential risk of vertical transmission of this microorganism.

\section{MATERIALS AND METHODS}

\section{Campylobacter sp in breeder hen crops}

In a crop of weighed breeder hens from a commercial grange located in the state of Minas Gerais, Brazil, samples from the vents of 140 chickens aged 58 weeks were collected with the aid of sterile swab. The chickens were identified with numbered ring sets on their wings. The samples were kept in Clary Blair transportation broth (Oxoid $\AA$ ) and sent to the laboratory for microbiological analysis.

*Corresponding Author. Mailing address: Laboratório de Biotecnologia Animal Aplicada, Faculdade de Medicina Veterinária, Universidade Federal de Uberlândia, Campus Umuarama. 38402-018, Uberlândia, MG, Brasil. Fax: (+5534) 3218-2380. E-mail: bialucas@yahoo.com.br 
Approximately four hours after collection at a refrigeration temperature $\left(6^{\circ} \mathrm{C}\right)$, the individualized and identified swab of each breeder hen was enriched in a tube containing $50 \mathrm{~mL}$ of Bolton broth $(\mathrm{Oxoid} \AA)$ supplemented with $5 \%$ of hemolyzed ovine blood and the following antibiotic mixture: $20 \mathrm{mg} / \mathrm{L}$ of sodium cefoperazone (Oxoid $\left.{ }^{\circledR}\right), 20 \mathrm{mg} / \mathrm{L}$ of vancomicine, $20 \mathrm{~g} / \mathrm{L}$ of trimethoprim, $50 \mathrm{mg} / \mathrm{L}$ of cycloheximide. This material was incubated in a microaerobic atmosphere (Probac microaerobic generator $\left.{ }^{\circledR}\right)$ at $42^{\circ} \mathrm{C}$ for 24 hours.

After enrichment, aliquots of each culture were seeded on Brucella agar (Oxoid $\left.{ }^{\circledR}\right)$ supplemented with the same antibiotic mixture, hemolyzed ovine blood and FBP supplement $(0.4 \mathrm{~g} / \mathrm{L}$ of sodium pyruvate, $0.4 \mathrm{~g} / \mathrm{L}$ of ferrous sulphate and $0.4 \mathrm{~g} / \mathrm{L}$ of sodium metasulphite). The plates were incubated at $37^{\circ} \mathrm{C}$ for 48 hours in an anaerobic jar under a microaerobic atmosphere.

The characteristic colony-forming units that appeared on the plates were confirmed as Campylobacter sp by gram staining and further examined under phase-contrast microscopy for typical movement and morphology. The cells with curved, S-shaped or spiral rod morphology, 0.2 to $0.9 \mu \mathrm{m}$ wide and 0.5 to $5.0 \mu \mathrm{m}$ long were classified as Campylobacter $\mathrm{sp}$.

In accordance with the results, the cloacal swab positive matrixes were isolated in a bay inside the aviary in a ratio of $7.5 \%$ of non-analyzed males to the number of females.

\section{Campylobacter sp in eggs}

The eggs from the hens that were cloacal swabs positive for Campylobacter sp were aseptically collected during seven consecutive weeks, resulting in a total of 244 eggs. Of these, 129 were underwent a process of dry disinfection $\left(12 \mathrm{~g} / \mathrm{m}^{3}\right.$ of paraformaldehyde gas 98\%/20 minutes) and 115 were sent to the laboratory immediately after collection, without any kind of disinfection. Campylobacter sp was researched in the macerated shells and in the yolks.

After 12 hours of the collected specimens being kept in the laboratory at room temperature, the disinfected and nondisinfected eggs were broken. Approximately $10 \mathrm{~g}$ of the macerated shells and $10 \mathrm{~g}$ of the yolk were seeded in $50 \mathrm{~mL}$ of Bolton broth and incubated at $42^{\circ} \mathrm{C}$ during 24 hours in a microaerobic atmosphere. The isolation and identification procedures were the same as those used for the cloacal swab from the breeder hens.

\section{RESULTS}

Campylobacter sp was detected in the vent of $25(17.8 \%)$ out of 140 analyzed breeder hens.

The presence of Campylobacter sp was not detected either in the macerated shells or in the yolk of the 244 eggs from the cloacal swab positive breeder hens, neither in the "smoked" eggs nor in the ones with no special treatment.

\section{DISCUSSION}

It was expected that cloacal swab positive breeder hens would have eggs shown to be positive at least in the macerated shells of "non-smoked" egg examinations. The results obtained in this research were unable to demonstrate the presence of Campylobacter sp in the macerated shell samples. This result diverges from the finding of Doyle (5) and Shanker et al. (14) who detected $0.8 \%$ and $1.0 \%$, respectively, in Campylobacter jejuni positive matrix egg shells. Neill et al. (10) found the bacterium in the egg shell, but they were limited to the interior of the shell membrane.

In the present research the egg shell negativity is probably due to desiccation, because Campylobacter is very sensitive to dehydration and atmospheric conditions (6).

No positive results were found in the yolk. These findings are similar to the other authors. Doyle (5) did not find the bacterium in the internal contents of the eggs after they had been in contact with Campylobacter culture at three different temperatures. Similar results were reported by Rabie (11), Baker (3), Zaki and Reda (17). Sahin et al. (12) demonstrating that Campylobacter has a limited capacity of penetrating egg shell, as they were unable to detect the microorganisms in 500 fresh eggs from cops of breeder hens that eliminated Campylobacter in their feces, or from eggs of breeder hens obtained from a commercial incubator.

Campylobacter width ( 0.2 to $0.8 \mu \mathrm{m})$ and length (0.5 to 5.0 $\mu \mathrm{m})(16)$ are significantly smaller than the pores of an egg shell, which measure 11 to $12 \mu \mathrm{m}$. The fowl temperature of $42^{\circ} \mathrm{C}(13)$ is ideal for allowing survival of the three most important species for aviculture classified as thermotolerating, and Campylobacter jejuni may naturally be present in different segments of the reproductive tracts of crops of commercial chickens (4). These physiological features of the egg and the chicken, as well as the bacterium characteristics, lead the authors of the present study to believe that it may be possible for Campylobacter sp to enter inside the eggs.

Studies conducted by Sahin et al. (12) on chicken eggs, and Maruyama et al. (9) on quails' eggs, showed that Campylobacter jejuni viability is sharply reduced when the bacterium is inoculated inside the albumen. It is possible that there may be some substance or factor in the egg albumin content that hinders the survival of this microorganism inside the eggs.

Experimental evidences suggest that under certain conditions $C$. jejuni generates viable but non-culturable forms, especially in Biofilms derived from aviaries (15). Hiett et al. (7) also demonstrated 70\% Campylobacter sp in eggs by direct Polymerase Chain Reaction (PCR), but these eggs were 100\% negative with the traditional culture methods, suggesting that Campylobacter could be present in eggs, however, without it being possible to isolate it.

The results of this research suggest that the capability of Campylobacter sp to reach the interior and/or survive within 
the egg is quite limited. Therefore, it is probable that vertical transmission is an unusual event in breeder hens, and that there are others infection routes for these animals. However, future researches using molecular biology must be conducted in an attempt to demonstrate viable non-culturable cells of Campylobacter sp inside eggs.

\section{RESUMO}

\section{Campylobacter sp em ovos provenientes de matrizes pesadas com $s w a b$ cloacal positivo}

Campylobacter sp é reconhecida como uma das principais causas de gastrenterite humana de origem alimentar. Dentre os alimentos veiculadores desses microrganismos, a carne de frango tem sido a mais implicada. Os estudos existentes sobre a transmissão vertical da Campylobacter são escassos e não conclusivos. O objetivo desse estudo foi verificar a presença de Campylobacter sp na casca e interior de ovos de matrizes positivas em swabs cloacais e a possibilidade de transmissão vertical. Foram analisados swabs cloacais de 140 matrizes pesadas e seus ovos colhidos para análise durante 7 semanas consecutivas. Dos 244 ovos colhidos, 129 foram fumigados e 115 analisados sem tratamento. Foram analisados o macerado da casca e a gema. Das 140 matrizes pesquisadas, $25(17,8 \%)$ foram positivas em swabs cloacais. Não houve positividade em nenhuma das amostras de ovos, independente da fumigação ou período de coleta. Apesar das características fisiológicas das matrizes, dos ovos e da Campylobacter sp serem favoráveis à entrada e sobrevivência da bactéria nos ovos, nesse estudo, nenhuma positividade foi encontrada, tanto no macerado da casca quanto na gema dos ovos, indicando que a transmissão vertical é possivelmente um evento raro.

Palavras-chave: Campylobacter, ovos, galinhas, transmissão vertical, epidemiologia

\section{REFERENCES}

1. Aquino, M.H.C.; Franco, R.M.; Tibana, A. Campylobacter jejuni na avicultura: importância e método de controle. Hig. Alim., 9, 36:1719, 1995.

2. Bailey, J.S. Control of Salmonella and Campylobacter in Poultry Production. Summary of Work at Russel Research Center. Poult. Sci., 72, 1169-1173, 1993.

3. Baker, R.C.; Paredes, M.D.; Qureshi, R.A. Prevalence of Campylobacter jejuni in eggs and poultry meat in New York State. Poult. Sci., 66(11), 1766-1770, 1987.

4. Buhr, R.J.; Cox, N.A.; Stern, N.J.; Musgrove, J.L.; Wilson, J.L.; Hiett, K.L. Recovery of Campylobacter from segments of the reproductive tract of broiler breeder hens. Avian Dis., 46, 919-924, 2002.

5. Doyle, M.P. Association of Campylobacter jejuni with laying hens and eggs. Appl. Environ. Microbiol., 47(3), 533-536, 1984.

6. Evans, S.A. Epidemiological studies of Salmonella and Campylobacter in poultry. London, 1997, 151p. (Ph.D. Thesis. University of London, London, United Kingdom).

7. Hiett, K.L.; Cox, N.A.; Stern, N. Direct Polymerase Cahin Reaction Detection of Campylobacter spp. In Poultry Hatchery Samples. Avian Dis., 46(1), 219-223, 2002.

8. Machado, R.A.; Tosin, I.; Leitão, M.F.F. Occurrence of Salmonella sp e Campylobacter sp. In chickens during industrial processing. Rev. Microbiol., 25, 239-244, 1994.

9. Maruyama, S.; Morita, Y.; Katsub, Y. Invasion and viability of Campylobacter jejuni in experimentally contaminated Japanese quails' eggs. J. Vet. Med. Sci., 57(3), 587-590, 1995.

10. Neill, S.; Campbell, J.; O'brien, J. Egg penetration by Campylobacter jejuni. Avian. Dis., 14, 313-320, 1985

11. Rabie, N.S.M. Studies on Campylobacteriosis in chickens. Cairo, 1992, 160p. (Ph. D. Thesis. Faculty of Veterinary Medicine. Cairo University).

12. Sahin, O.; Kobalka, P.; Zhang, Q. Detection and survival of Campylobacter in chicken eggs. J. Appl. Microbiol., 95(5), 10701074, 2003.

13. Sesti, L.A.; Ito, N.M.K. Enfermidades do Sistema Reprodutor. In: Berchieri Jr, A.; Macari, M. (eds). Doença das Aves, FACTA Fundação APINCO de Ciência e Tecnologia Avícolas, Campinas, S.P, 2000. p.81-128.

14. Shanker, S.; Lee, A.; Sorrell, T.C. Campylobacter jejuni in broilers: the role of vertical transmission. J. Hyg., 96, 153-159, 1986.

15. Trachoo, N.; Frank, J.F.; Stern, N.J. Survival of Campylobacter jejuni biofilms isolated from chicken houses. J. Food Prot., 65 , 1110-1116, 2002.

16. Vandamme, P. Taxonomy of the family Campylobacteraceae. In Nachamkin, I.; Blaser, M.J. Campylobacter, 2.ed., American Society for Microbiology, Washington, D.C, 2000. p.3-26.

17. Zaki, M.M.; Redda, W.W. Campylobacteriosis in Poultry. Vet. Med. J. Giza., 43(1), 71-76, 1995. 